\title{
Association between Living Conditions and Admission to an Inappropriate Ward in Elderly Patients
}

\section{Diane Naouri ( $\sim$ naouri.diane@gmail.com )}

Centre for Research in Epidemiology and Population Health, INSERM U1018, Université Paris-Saclay, Université Paris-Sud, UVSQ, Villejuif, France

Henri Panjo

Centre for Research in Epidemiology and Population Health, INSERM U1018, Université Paris-Saclay, Université Paris-Sud, UVSQ, Villejuif, France

\section{Laura Moïsi}

Sorbonne Université, AP-HP, Hôpital Saint Antoine, Unité de Gériatrie aigue

\section{Carlos El Khoury}

French Society of Emergency Medicine (SFMU)

\section{Patrice Serre}

French Society of Emergency Medicine (SFMU)

\section{Jeannot Schmidt}

French Society of Emergency Medicine (SFMU)

\section{Youri Yordanov}

Sorbonne Université, AP-HP, Hôpital Saint Antoine, INSERM, Institut Pierre Louis d'Epidémiologie et de Santé Publique, UMR-S 1136

\section{Nathalie Pelletier-Fleury}

Centre for Research in Epidemiology and Population Health, INSERM U1018, Université Paris-Saclay, Université Paris-Sud, UVSQ, Villejuif, France

\section{Research Article}

Keywords: hospitalizations, emergency department (ED), inappropriate wards (IWs), health care costs

Posted Date: April 5th, 2021

DOI: https://doi.org/10.21203/rs.3.rs-376211/v1

License: (c) (i) This work is licensed under a Creative Commons Attribution 4.0 International License. Read Full License 
4 Naouri D. ${ }^{1}$ MD MSc; Panjo H. ${ }^{1}$ PhD; Moïsi L. ${ }^{2}$ MD MSc; El Khoury C. ${ }^{3}$ MD PhD; Serre P. ${ }^{3}$ MD;

5 Schmidt J. ${ }^{3}$ MD PhD; Yordanov Y..$^{4 *}$ MD PhD; Pelletier-Fleury N. ${ }^{*}$ MD. PhD

$7 \quad{ }^{1}$ Centre for Research in Epidemiology and Population Health, French National Institute of Health and Medical

8 Research (INSERM U1018), Université Paris- Saclay, Université Paris-Sud, UVSQ, Villejuif, France

$9 \quad{ }^{2}$ Sorbonne Université, AP-HP, Hôpital Saint Antoine, Unité de Gériatrie aigue, Paris, France

$10 \quad{ }^{3}$ French Society of Emergency Medicine (SFMU)

$11{ }^{4}$ Sorbonne Université, AP-HP, Hôpital Saint Antoine, Service d'Accueil des Urgences, INSERM, Institut Pierre

12 Louis d'Epidémiologie et de Santé Publique, UMR-S 1136, Paris, France

14 *NPF and YY contributed equally to the work

16 Corresponding author: Dr Diane Naouri

Word count: 2811 


\section{ABSTRACT}

36 INTRODUCTION. Half of elderly patient hospitalizations are preceded by an emergency 37 department (ED) visit, and a higher proportion is observed among those living in institutions.

38 These patients are more often exposed to problems related to hospital occupancy and 39 overcrowding, which may lead to hospitalization in inappropriate wards (IWs) and increased 40 morbidity and health care costs. At the same time, elderly individuals living in institutions, due to

41 their high vulnerability, are the most exposed to these negative health care outcomes and might

42 have priority in geriatric beds. The aim of this study was to explore whether living conditions

43 were associated with admission to an IW after visiting an ED.

44 METHOD. The French Emergency Survey was a one-day, nationwide, cross-sectional survey in 452013 in all EDs in France. We focused on patients $\geq 75$ years old who had been hospitalized.

46 Descriptive analysis and multilevel logistic regression were used.

47 RESULTS. Among the 3,285 patients, 16.5\% were admitted to an IW: $15.7 \%$ among those

48 living in institutions and $16.6 \%$ among those living at home. ED visits during peak periods and

49 reaching the ED by her/his own means were the only factors associated with an increased

50 likelihood of admission to an IW. There was no association with living conditions.

51 CONCLUSION. Living conditions were not observed to be associated with the likelihood of

52 being hospitalized in an IW after an ED visit. Given the limited bed resources and the greater

53 vulnerability of elderly individuals living in institutions (compared with those living at home),

54 progress can be made in the coordination of acute geriatric care. 
59 In many industrialized countries, a high proportion of emergency department (ED) visits are for 60 non-urgent conditions (1-3), largely contributing to the well-known phenomenon of access block

61 and overcrowding (4,5), a source of additional morbidity $(6,7)$ and medical errors (8). Elderly

62 individuals represent an increasing proportion of ED users (9). It has been shown that they suffer

63 from suboptimal care in EDs (10-13). They wait longer $(10,11)$ and are at higher risk of poor 64 pain management (12) and adverse health outcomes after discharge (e.g., functional decline, ED 65 return, hospitalization, and death) (13). Elderly patients are also twice as likely to experience 66 delirium related to an ED length of stay (LOS) that exceeds 10 hours (14) and suffer from a 3\% 67 increase in the risk of adverse events per hour in an ED (such as procedure-related and/or 68 medication-related adverse events) (15). It is well-established that these prolonged ED LOSs are 69 largely due to the inability to access inpatient beds for these elderly people $(16,17)$, often 70 considered bed blockers $(18,19)$. In this context, several reports have stressed the need to

71 implement clinical pathways for direct admission (DA) to the hospital for these elderly patients to 72 improve the process and outcome $(20,21)$.

73 Advanced age actually brings a higher likelihood of presenting with multiple chronic 74 conditions and is accentuated by frequent socioeconomic issues (22) leading to frailty. Frailty is 75 the most problematic expression of population ageing (22,23). Such a condition of extreme 76 vulnerability exposes individuals to an increased risk of negative health-related outcomes leading 77 to disability, hospitalization, institutionalization, and death (22). In 2015, in France, 5.7\% of 78 people older than 65 years were living in institutions, 49\% of whom suffered from 79 neurodegenerative disease (24). Similar proportions are found in other countries (25). Older 80 people living in nursing homes have increased levels of comorbidity, frailty and physical health 81 needs (26). For this particular population, the implementation of clinical pathways from DA to 
82 hospitals seems slow to take place. In a recent study, $60 \%$ of hospitalizations of elderly 83 individuals living in institutions were preceded by an ED visit, compared with $45 \%$ of those 84 living at home (21).

85 Faced with this reality, the issue of appropriateness to the patient's needs in the hospital 86 ward to which the elderly are admitted for this unscheduled hospitalization $(27,28)$ seemed 87 important to consider. Several studies have shown that admission to wards dedicated to elderly 88 individuals (acute geriatric units) is associated with less delirium (29), better functional status 89 (28,30), higher likelihood of returning home $(28,30)$, and a shorter hospital stay (30). This

90 finding might be particularly true for those living in institutions, as they are more vulnerable than

91 others. To our knowledge, it has been minimally investigated. One can think, if not hope, that 92 special vigilance is being exercised with regard to these fragile patients and that they will be less 93 hospitalized in a ward that is not appropriate to their needs.

94 We took advantage of a nationwide cross-sectional survey that aimed to portray hospital95 based emergency care in France to explore whether living conditions were associated with the 96 likelihood of being hospitalized in an inappropriate ward after a visit to an emergency department 97 in elderly patients over 75 years. 


\section{French Emergency Survey}

108 The French Emergency Survey (FES) is a nationwide cross-sectional survey with a two-level 109 design that aims to portray hospital-based emergency care in France by describing ED 110 organizations and patients. It was developed by the French Society of Emergency Medicine 111 (SFMU) and the French Directorate of Research, Studies, Evaluation and Statistics at the

112 Ministry of Social Affairs and Health (DREES) and has already been described $(31,32)$.

113 Briefly, data were collected from 734 of the 736 adult and paediatric EDs listed in French

114 territory and described 48,711 patients who came to one of these EDs during a 24-hour period on

115 June 11, 2013. Collected data concerned the organization of the participating EDs, individual 116 characteristics, and care delivered in EDs. The first part of the survey was the ED-centred 117 questionnaire completed by each ED administrator. The second part of the survey was the patient

118 questionnaire, completed by the patient or the accompanying person under the supervision of the 119 emergency physician (EP) during the ED visit.

\section{Ethics}

122

This study was carried out in accordance with relevant guidelines and regulations. It was declared

124 to be of public interest by the National Council for Statistical Information (CNIS) and was

125 integrated into the public statistical program (Visa no. 2013X080SA and publication in the 126 official Journal of French Republic, September 17, 2013). It was also approved by the French 127 Data Protection Authority (CNIL) (identification no. 1663413). According to French law, written 128 informed consent was not required for this type of study. 
130 We selected all patients older than 75 years included in the FES (excluding those from overseas

131 territories) who were hospitalized. They could be admitted to the same hospital where the ED

132 was located or transferred to another hospital. Since information on the appropriateness of the

133 ward was not available in the event of inter-hospital transfer, the patients concerned were not

134 included in our main analysis and were described separately.

\section{Outcome of interest}

137 For every patient hospitalized in the same hospital where the ED was located (excluding inter138 hospital transfers), EPs were asked if the hospitalization took place in a ward they considered 139 inappropriate for the patient's needs (binary variable yes/no) (IW). An appropriate ward was

140 defined as the ward that would have been chosen by the EP if all the beds were available.

\section{Explanatory and adjustment variables}

143 Living conditions and other explanatory variables at the patient level as well as adjustment

144 variables are summarized in Table 1.

\begin{tabular}{|c|l|l|}
\hline \multicolumn{2}{|l|}{ PATIENT LEVEL } \\
\hline \multirow{4}{*}{$\begin{array}{c}\text { Individual } \\
\text { characteristics }\end{array}$} & Age & $75-84 \mathrm{y} / \geq 85 \mathrm{y}$ \\
\cline { 2 - 3 } & Gender & Female/Male \\
\cline { 2 - 3 } & Living conditions & Living at home/Living in an institution \\
\cline { 2 - 3 } & Having a referent GP & Yes/No \\
\cline { 2 - 3 } & Supplementary health & $\begin{array}{l}\text { Having universal health coverage (CMU-C) or not } \\
\text { Note: A large proportion of the population has private } \\
\text { supplementary health insurance to cover re-insurable co- } \\
\text { payments not covered by the public insurance scheme. } \\
\text { Below a certain income threshold, individuals can } \\
\text { benefit from a free supplementary health insurance } \\
\text { called CMU-C, which can be considered here as a proxy }\end{array}$ \\
\hline
\end{tabular}




\begin{tabular}{|c|c|c|}
\hline & & for poor socioeconomic status. \\
\hline \multirow{5}{*}{ ED visit-related } & Presenting complaint & Cardiopulmonary/Neurological/Traumatic injury/Other \\
\hline & Time of ED arrival & 8:00 a.m.-12:00 p.m./12:00 p.m.-8:00 p.m./after 8 p.m. \\
\hline & $\begin{array}{l}\text { How the questionnaire was } \\
\text { filled out }\end{array}$ & $\begin{array}{l}\text { With the patient/With a proxy/No response available } \\
\text { from both patient and proxy }\end{array}$ \\
\hline & $\begin{array}{l}\text { How the patient reached the } \\
\text { ED }\end{array}$ & $\begin{array}{l}\text { By his/her own means or by ambulance/With firefighters } \\
\text { or emergency medical services (SAMU) }\end{array}$ \\
\hline & $\begin{array}{l}\text { The distance from the patient's } \\
\text { home to the ED }\end{array}$ & $<10 \mathrm{~km} />10 \mathrm{~km}$ \\
\hline & $\begin{array}{l}\text { If the patient was managed in a } \\
\text { resuscitation room }\end{array}$ & $\begin{array}{l}\text { Yes/No } \\
\text { Note: It was considered here as a proxy for a life- } \\
\text { threatening condition }\end{array}$ \\
\hline & $\begin{array}{l}\text { If the ED used was that of the } \\
\text { usual place of residence }\end{array}$ & Yes/No \\
\hline & Type of hospitalization ward & $\begin{array}{l}\text { Medical ward/Surgery/Intensive care unit (ICU)/Long } \\
\text { term care/Psychiatry }\end{array}$ \\
\hline \multicolumn{3}{|c|}{$\begin{array}{l}\text { Note: To analyse the factors associated with the admission to an inappropriate ward (IW), we performed analyses } \\
\text { adjusted on characteristics of health care supply and demand at the ED level. } \\
\text { The survey included variables about the ED and the county in which the ED was located. }\end{array}$} \\
\hline \multirow{4}{*}{$\begin{array}{l}\text { Characteristics of } \\
\text { healthcare demand }\end{array}$} & ED attendance & $\begin{array}{l}\text { Number of annual visits to the ED }(<15,000,15,000- \\
30,000,30,000-45,000,>45,000)\end{array}$ \\
\hline & Elderly rate & $\begin{array}{l}\text { Proportion of elderly patients among those coming to } \\
\text { the ED (above and below the median) }\end{array}$ \\
\hline & $\begin{array}{l}\text { Proportion of dependent } \\
\text { persons among patients older } \\
\text { than } 75 \text { years in the county }\end{array}$ & $\begin{array}{l}\text { Above and below the national average of } 20.6 \% \\
\text { Note: Dependent persons were identified as those } \\
\text { receiving the personalized autonomy allowance (APA) } \\
\text { awarded to those with issues with activities of daily } \\
\text { living. }\end{array}$ \\
\hline & $\begin{array}{l}\text { Number of access blocks to } \\
\text { patients }\end{array}$ & $\begin{array}{l}\text { The number of patients on a stretcher waiting to be } \\
\text { admitted to a ward at } 8: 00 \text { a.m. on the day of the survey) } \\
\text { ( } 0 \text { patient } / \geq 1 \text { patient). } \\
\text { Note: It was considered an indicator of ED } \\
\text { overcrowding (which is known to be linked to access } \\
\text { block }(4,5,16) \text { ) and is a negative outcome for health care } \\
\text { system efficiency when it is greater than } 0 .\end{array}$ \\
\hline & Type of hospital & $\begin{array}{l}\text { Public academic/public non-academic and/or not-for } \\
\text { profit private hospitals/for-profit private hospitals }\end{array}$ \\
\hline & $\begin{array}{l}\text { Number of hospitalization beds } \\
\text { in the acute medical unit in the } \\
\text { hospital }\end{array}$ & $\begin{array}{l}\text { Number of hospitalization beds in the acute medical unit } \\
\text { (in the same hospital where the ED was located) per } \\
10,000 \mathrm{ED} \text { annual visits }\end{array}$ \\
\hline & $\begin{array}{l}\text { Percent of geriatric unit beds in } \\
\text { the hospital }\end{array}$ & $\begin{array}{l}\text { Percent of geriatric unit beds among all acute medical } \\
\text { beds. It was equal to } 0 \text { in case of no geriatric unit in the } \\
\text { same hospital where the ED was located }\end{array}$ \\
\hline
\end{tabular}




\begin{tabular}{|c|c|c|}
\hline \multirow[t]{5}{*}{$\begin{array}{l}\text { Characteristics of health } \\
\text { care supply }\end{array}$} & $\begin{array}{l}\text { Number of long-term care and } \\
\text { nursing home beds per } 100,000 \\
\text { patients older than } 75 \text { years in } \\
\text { the county }\end{array}$ & Above/Below the national average of 123.4 beds, \\
\hline & $\begin{array}{l}\text { Proportion of available places } \\
\text { in nursing homes for patients } \\
\text { older than } 75 \text { years in the } \\
\text { county }\end{array}$ & Above/Below the national average rate of $19.6 \%$, \\
\hline & $\begin{array}{l}\text { Number of acute care beds per } \\
100,000 \text { inhabitants in the } \\
\text { county }\end{array}$ & Above/Below the national average of 395 beds \\
\hline & $\begin{array}{l}\text { Nurse density per } 100,000 \\
\text { inhabitants in the county }\end{array}$ & Above/Below the national average density of 146 (33) \\
\hline & $\begin{array}{l}\text { Medical density (all specialties } \\
\text { combined) per } 100,000 \\
\text { inhabitants in the county }\end{array}$ & $\begin{array}{l}\text { It was classified into } 3 \text { levels: Low/Medium/High) (34). } \\
\text { In } 2013 \text {, low, medium, and high levels corresponded to } \\
<302,302 \text { to } 393 \text { and }>393 \text { doctors, respectively. }\end{array}$ \\
\hline
\end{tabular}

Table 1. List of explanatory and adjustment variables

\section{Statistical analysis}

150 (35) to handle missing data for individual characteristics (except the outcome of interest) under

151 the assumption of missing at random (MAR). Ten imputed datasets were created for analysis, and

152 the regression coefficients were acquired by combining the results from the imputed datasets and 153 applying Rubin's rules (36).

154 Descriptive analysis. The characteristics of the study population (individual

155 characteristics and ED visit-related variables) before and after imputation were described, as well

156 as characteristics at the ED level (characteristics of health care demand and supply). Categorical

157 variables were reported as numbers (\%). 
159 logistic regression model was built for those who were hospitalized in the same hospital where 160 the ED was located. We also performed sensitivity analysis, including inter-hospital transfers, 161 considering them admissions to appropriate wards.

162 A multilevel logistic regression model allowed us to consider the hierarchical structure of

163 the data and explain admission to an IW according to the study population's characteristics after 164 adjustment for variables at the ED level. First, we tested the non-adjusted model (the empty 165 model), considering only the cluster effect but no explanatory variable. The aim of this first step 166 was to confirm possible inter-group (inter-ED) heterogeneity and justify the multilevel approach.

167 The intraclass correlation coefficient obtained in the empty model indicated that approximately $16825 \%$ of the total variance of admission to an IW was explained by the ED level. We also tested 169 the county level but did not find intergroup heterogeneity. Variables that were statistically 170 significant in univariate analysis at $\mathrm{p}<0.20$ were introduced in our models. Age, living conditions, 171 number of long-term care and nursing home beds in the county, and number of acute care beds in 172 the county were also included in the model even if the p-value was $>0.20$.

173 All statistical analyses were performed using SAS software (SAS/STAT Package 2002-2003 by 174 SAS Institute Inc., Cary, NC, USA). 


\section{Characteristics of study participants}

187 Among the 3,285 patients 75 years or older included in the FES, 3,005 (91.5\%) were admitted to 188 the same hospital where the ED was located, and 280 (8.5\%) were transferred (Figure 1).

189 The descriptive results are summarized in Table 2. Among the 3,005 patients older than 75 years 190 who were admitted to the same hospital where the ED was located, admission occurred to an 191 intensive care unit (ICU) for $8.0 \%$ of the patients $(\mathrm{n}=280)$, to surgery for $22.0 \%(\mathrm{n}=716)$ and to a 192 medical ward for $68.8 \%(\mathrm{n}=2235)$. In all, 59.1\% $(\mathrm{n}=1941)$ were women, $47.1 \%(\mathrm{n}=1515)$ were 85 193 years or older and $15.1 \%(\mathrm{n}=482)$ were living in an institution. Approximately $80 \%$ of these ED 194 visits $(\mathrm{n}=2622)$ occurred between 8 a.m. and 8 p.m. Among those who were not transferred, $19516.5 \%(\mathrm{n}=495)$ were admitted to a ward considered inappropriate: $15.7 \%(\mathrm{n}=69)$ of those living 196 in institutions versus $16.6 \%(\mathrm{n}=426)$ of those living at home. The characteristics of the study 197 participants by living conditions are summarized in Table 3.

199 Characteristics of health care demand and supply at the ED level

200 Among the 593 EDs involved in the study, only $18.7 \%(\mathrm{n}=111)$ were for-profit private hospitals, $20133.5 \%(\mathrm{n}=199)$ had more than 30,000 annual visits and 36.1\% $(\mathrm{n}=214)$ had at least one access 202 block patient on the day of the study (Table 4).

\section{Multilevel regression models}

205 After adjustment for characteristics of health care supply and demand at the ED level, ED visits 206 during peak periods (in the afternoon or at night $v s$. in the morning) and reaching the ED by 207 her/his own means or by ambulance were the only factors associated with an increased likelihood 
208 of admission to an IW (Table 5). Living conditions were not associated with the likelihood of 209 admission to an IW.

210

\section{Sensitivity analysis.}

212 When considering inter-hospital transfers as admissions to an appropriate ward, the results from 213 the multilevel regression model were similar (Appendix 2).

214

215

216

217

218

219

220

221

222

223

224

225

226

227

228

229

230

231

232

233

234

235

236

237

238

239

240

241

242

243

244

245

246

247

248 
250 Our study shows that $16.5 \%$ of the elderly individuals over 75 years of age referred to the ED and

251 hospitalized are in a service that is inappropriate to their needs and that being institutionalized

252 does not reduce this percentage. Thus, our hypothesis that special vigilance is being exercised

253 with regard to these fragile patients is not confirmed. As ED visits would already be considered a

254 negative health care outcome, it appears that older people living in institutions are subject to a

255 double penalty, that of being admitted less often directly to a hospital service (21) and that of not

256 being cared for with more attention than other elderly patients when the decision to hospitalize is

257 made.

258 Being admitted to an inappropriate ward.

259 Since 2000, the number of beds per capita has decreased in nearly all OECD countries, from an 260 average of 5.6 per 1000 of the population to 4.7 in 2017, which can be attributed, in part, to cost 261 and financial constraints (37). This reduction in bed capacity can increase hospital occupancy, 262 which might impact the proper functioning of hospitals and can be detrimental to patient 263 outcomes (38). Higher inpatient volumes and demand for beds results in a reduced ability to 264 manage fluctuating incoming patient flow with available resources (39). A potential consequence 265 of high occupancy is that patients may be admitted to any available bed regardless of the reason 266 for the visit. The magnitude of this phenomenon, $16.5 \%$ in this study, is poorly documented in 267 the literature $(40,41)$. One could criticize the subjectivity of this criterion being assessed by the 268 emergency physician. However, who can judge the situation better than the doctor? In any case, 269 to our knowledge, there is no objective criterion for measurement.

270 Failure in upstream and post-ED organization.

271 Elderly individuals living in institutions are not only the most vulnerable, but when upstream 272 coordination fails (i.e., the patients are referred to EDs), they will also not be cared for with more 
273 attention than other elderly patients. Even if they would probably benefit the most from the

274 expertise of geriatricians and would suffer the most from the lack of hospitalization beds adapted

275 to their needs. It suggests that hospital occupancy is so high that priority for institutionalized

276 people is no longer possible due to adaptation capacities already being exceeded (39). Some

277 studies have shown that better management of inpatient beds (such as early morning admissions)

278 is associated with increased systemic capacity and reduces the number of ED access blocks $(5,42)$.

279 Other solutions proposed would be to improve the balance between the demand and supply of

280 hospital beds by reducing the demand (improving upstream services and identifying

281 vulnerability) and increasing the supply. For example, several studies have shown that acute

282 geriatric unit LOS increased when the patient was waiting for long-term care facilities and/or a

283 nursing home (43-45). Holstein J et al proposed dividing acute geriatric unit LOS into "medical

284 stay" (with a high concentration of medical explorations and costs) and "social stay" (including

285 waiting time for long-term care) (44). The duration of the "social stay", which could reach up to

$28618 \%$ of LOS, depends on the availability of beds in long-term care units and/or nursing homes

287 (44). Increasing the number of beds in the entire geriatric pathway as well as social service

288 resources would allow all vulnerable elderly patients to be identified early and receive suitable

289 geriatric and social expertise to improve geriatric service $(18,45,46)$. Few studies have

290 investigated the link between primary care interventions on coordination of care and

291 appropriateness of ward admission for elderly patients $(47,48)$. An integrated primary care model

292 for very frail elderly individuals decreases the risk of unplanned hospital admission and increases

293 the rate of planned admissions (47). Additionally, DA to geriatric intermediate care units might

294 represent a potential alternative to acute hospitalization for selected older patients (48).

\section{The double penalty: a major consideration for those living in institutions}


296 It is already well-known that elderly individuals living in institutions are more likely to be

297 referred to the ED before hospitalization than those living at home (21). We also know that 298 prolonged ED LOS, often related to difficulties in managing cognitive disorders and physical 299 impairment in this population, is associated with discharge delays and longer hospital stays (49300 51). Strategies to reduce ED LOS may also save both ED costs and costs associated with 301 inpatient care (49), which is why such strategies of avoiding ED visits by DA should be preferred 302 for those living in institutions.

\section{Poor feasibility of $\mathrm{DA}$}

304 Possible barriers to the diffusion of DA are the difficulty of organizing it in routine practice 305 within a reasonable time $(52,53)$ and a common belief that access to certain tests, particularly 306 radiological tests, would be easier from the ED than from hospitalization wards. From experts' 307 views, strategies of reserving beds dedicated to DA could enhance their availability, and thus, 308 encourage physicians to organize geriatric care pathways, especially for fragile patients living in 309 institutions.

\section{$310 \quad$ Poor health care coordination in institutions}

311 Excess ED referrals could also be related to dysfunction in health care management in institutions 312 themselves. Indeed, $80 \%$ of ED visits occurred in daytime. During the daytime, urgent medical 313 advice should be possible within the institution, and care could be initiated until DA becomes 314 possible. In 2015, in France, there were on average 22.8 caregivers (nurses and nursing 315 assistants) per 100 elderly individuals in private institutions and 36.7 in public institutions (54).

316 Among all institutions, 44\% reported recruitment difficulties, more frequently in private 317 institutions (54). Understaffing was reported in $63 \%$ of institutions, especially among 318 coordinating physicians (10\%) and nursing assistants (9\%) (54). Understaffing and inadequate 319 training of nursing staff are known to be associated with poor quality of care (55). 
320 Each country, depending on its health system and the political choices that are made, tries to

321 address these problems in a different way.

\section{Limitations}

323 Our study has several limitations. The first limitation is the lack of data on comorbidities

324 (including the presence of cognitive disorders) and the degree of patient autonomy, which would

325 have allowed us to perform a more detailed analysis of patient characteristics. Unfortunately,

326 these variables were not collected in the survey. However, we assume that these variables might

327 be strongly linked to older age and living conditions and that a lack of information might have

328 limited consequences.

329 The second limitation concerns the exclusion of inter-hospital transfers (because of missing data

330 on the outcome of interest). However, sensitivity analysis (assuming that all patients were

331 transferred to an appropriate ward) did not show differences in the results of the multilevel

332 models.

333 The last limitation is that this survey reflects the situation in EDs in 2013 and that it might have

334 changed since 2013. However, this study takes part in a ministerial study plan on EDs, taking

335 place every 10 years where 2013 was the first nationwide survey. In 2003, the study involved a

336 sample of EDs only. It is, thus, the most recent national data source available on EDs at this time. 


\section{CONCLUSION}

343 Living conditions were not statistically associated with the likelihood of being hospitalized in an

344 inappropriate ward after a visit to an emergency department. This finding suggests that elderly

345 people living in institutions, who should be considered as more vulnerable than those living at

346 home, are not prioritized in access to hospital beds. These results argue for the development of

347 geriatric care pathways, especially for the most fragile elderly.

348

349

350

351

352

353

354

355

356

357

358

359

360

361

362

363

364

365 
367 1. Cour des comptes. Les urgences hospitalières : une fréquentation croissante, une 368 articulation avec la médecine de ville à repenser [Internet]. 2014 [cited 2019 Jun 19] p.

369 351-77. (Rapport sur l'application des lois de financement de la sécurité sociale pour 2014). 370 Available from:

371 https://www.ccomptes.fr/sites/default/files/EzPublish/rapport_securite_sociale_2014_urg 372 ences_hospitalieres.pdf

373 2. Uscher-Pines L, Pines J, Kellermann A, Gillen E, Mehrotra A. Emergency department visits for nonurgent conditions: systematic literature review. Am J Manag Care. 2013 Jan;19(1):47-59.

376 3. Naouri D, Ranchon G, Vuagnat A, Schmidt J, El Khoury C, Yordanov Y, et al. Factors 377 associated with inappropriate use of emergency departments: findings from a cross378 sectional national study in France. BMJ Qual Saf. 2019 Oct 30;

379 4. Shetty AL, Teh C, Vukasovic M, Joyce S, Vaghasiya MR, Forero R. Impact of emergency 380 department discharge stream short stay unit performance and hospital bed occupancy rates 381 382

383 384 385 on access and patient flowmeasures: A single site study. Emerg Med Australas EMA. 2017 Aug;29(4):407-14.

5. Luo W, Cao J, Gallagher M, Wiles J. Estimating the intensity of ward admission and its effect on emergency department access block. Stat Med. 2013 Jul 10;32(15):2681-94.

6. Jo S, Jin YH, Lee JB, Jeong T, Yoon J, Park B. Emergency department occupancy ratio is associated with increased early mortality. J Emerg Med. 2014 Feb;46(2):241-9.

7. Richardson DB. Increase in patient mortality at 10 days associated with emergency department overcrowding. Med J Aust. 2006 Mar 6;184(5):213-6.

8. Kulstad EB, Sikka R, Sweis RT, Kelley KM, Rzechula KH. ED overcrowding is associated with an increased frequency of medication errors. Am J Emerg Med. 2010 Mar;28(3):304-9.

9. Samaras N, Chevalley T, Samaras D, Gold G. Older Patients in the Emergency Department: A Review. Ann Emerg Med. 2010 Sep;56(3):261-9.

10. Horwitz LI, Bradley EH. Percentage of US emergency department patients seen within the recommended triage time: 1997 to 2006. Arch Intern Med. 2009 Nov 9;169(20):1857-65.

11. Freund Y, Vincent-Cassy C, Bloom B, Riou B, Ray P, APHP Emergency Database Study Group. Association between age older than 75 years and exceeded target waiting times in the emergency department: a multicenter cross-sectional survey in the Paris metropolitan area, France. Ann Emerg Med. 2013 Nov;62(5):449-56.

12. Platts-Mills TF, Esserman DA, Brown DL, Bortsov AV, Sloane PD, McLean SA. Older US emergency department patients are less likely to receive pain medication than younger patients: results from a national survey. Ann Emerg Med. 2012 Aug;60(2):199-206. 13. Aminzadeh F, Dalziel WB. Older adults in the emergency department: A systematic review of patterns of use, adverse outcomes, and effectiveness of interventions. Ann Emerg Med. 2002 Mar;39(3):238-47.

14. Bo M, Bonetto M, Bottignole G, Porrino P, Coppo E, Tibaldi M, et al. Length of Stay in the Emergency Department and Occurrence of Delirium in Older Medical Patients. J Am Geriatr Soc. 2016 May 1;64(5):1114-9.

410 15. Ackroyd-Stolarz S, Guernsey JR, MacKinnon NJ, Kovacs G. The association between a 
411 prolonged stay in the emergency department and adverse events in older patients admitted 412 to hospital: a retrospective cohort study. BMJ Qual Saf. 2011 Jul 1;20(7):564-9.

413 16. Cooke MW, Wilson S, Halsall J, Roalfe A. Total time in English accident and

414 emergency departments is related to bed occupancy. Emerg Med J EMJ. 2004

415 Sep;21(5):575-6.

416 17. Forero R, McCarthy S, Hillman K. Access block and emergency department

417 overcrowding. Crit Care. 2011;15(2):216.

418 18. Manzano-Santaella A. From bed-blocking to delayed discharges: precursors and 419 interpretations of a contested concept. Health Serv Manage Res. 2010 Aug 1;23(3):121-7.

$42019 . \quad$ Vetter N. Inappropriately delayed discharge from hospital: What do we know? BMJ.

4212003 Apr 26;326(7395):927-8.

422 20. Cours des comptes. Les urgences hospitalières : une fréquentation croissante, une

423

424

425

426

427

428

429

430

431

432

433

434

435

436

437

438

439

440

441

442

443

444

445

446

447

448

449

450

451

452

453

454

455

456 https://www.ccomptes.fr/sites/default/files/EzPublish/rapport_securite_sociale_2014_urg ences_hospitalieres.pdf

21. Mesnier T. Assurer le premier accès aux soins Organiser les soins non programmés dans les territoires [Internet]. 2018 May. Available from: https://solidaritessante.gouv.fr/IMG/pdf/rapport_snp_vf.pdf

22. Cesari M, Calvani R, Marzetti E. Frailty in Older Persons. Clin Geriatr Med. 2017;33(3):293-303.

23. Clegg A, Young J, Iliffe S, Rikkert MO, Rockwood K. Frailty in elderly people. The Lancet. 2013 Mar 2;381(9868):752-62.

24. Direction de la recherche des études de l'évaluation et des statistiques. Infographie : L'hébergement des personnes âgées en établissement - Les chiffres clés [Internet]. [cited 2021 Jan 14]. Available from: https://drees.solidarites-sante.gouv.fr/etudes-etstatistiques/publications/infographies/article/infographie-l-hebergement-des-personnesagees-en-etablissement-les-chiffres

25. British Geriatrics Society. Joint Working Party Inquiry into the Quality of Healthcare Support for Older People in Care Homes: A Call for Leadership, Partnership and Quality Improvement [Internet]. 2011 Jun. Available from:

https://www.bgs.org.uk/sites/default/files/content/attachment/2019-08-

27/quest_quality_care_homes.pdf

26. Sampson EL, Feast A, Blighe A, Froggatt K, Hunter R, Marston L, et al. Evidence-based intervention to reduce avoidable hospital admissions in care home residents (the Better

Health in Residents in Care Homes (BHiRCH) study): protocol for a pilot cluster randomised trial. BMJ Open. 2019 May 1;9(5):e026510.

27. Moulias R, Moulias S, Franco A, Meaume S. Le syndrome du soin inapproprié. Une situation gériatrique courante sévère, mais curable. Rev Gériatrie. 2012;37(5):1.

28. Baztán JJ, Suárez-García FM, López-Arrieta J, Rodríguez-Mañas L, Rodríguez-Artalejo F. Effectiveness of acute geriatric units on functional decline, living at home, and case fatality among older patients admitted to hospital for acute medical disorders: metaanalysis. BMJ. 2009 Jan 22;338:b50.

29. Bo M, Martini B, Ruatta C, Massaia M, Ricauda NA, Varetto A, et al. Geriatric ward hospitalization reduced incidence delirium among older medical inpatients. Am J Geriatr Psychiatry Off J Am Assoc Geriatr Psychiatry. 2009 Sep;17(9):760-8.

30. Asplund K, Gustafson Y, Jacobsson C, Bucht G, Wahlin A, Peterson J, et al. Geriatric- 
Based Versus General Wards for Older Acute Medical Patients: A Randomized Comparison of Outcomes and Use of Resources. J Am Geriatr Soc. 2000;48(11):1381-8.

459 31. Naouri D, El Khoury C, Vincent-Cassy C, Vuagnat A, Schmidt J, Yordanov Y, et al. The 460 French Emergency National Survey: A description of emergency departments and patients 461 in France. PloS One. 2018;13(6):e0198474.

462 32. Naouri D, Ranchon G, Vuagnat A, Schmidt J, Khoury CE, Yordanov Y. Factors

463

464

465

466

467

468

469

470

471

472

473

474

475

476

477

478

479

480

481

482

483

484

485

486

487

488

489

490

491

492

493

494

495

496

497

498

499

500

501 associated with inappropriate use of emergency departments: findings from a crosssectional national study in France. BMJ Qual Saf. 2019 Oct 29;bmjqs-2019-009396.

33. Professionnels de santé au 1er janvier 2017 | Insee [Internet]. [cited 2019 Sep 25].

Available from: https://www.insee.fr/fr/statistiques/2012677\#tableau-

TCRD_068_tab1_departements

34. Cartographie Interactive de la Démographie Médicale [Internet]. [cited 2019 Sep 25]. Available from: https://demographie.medecin.fr/\#s=2016;v=map2;i=demo_med.dens_tte_act;l=fr

35. Schafer JL, Olsen MK. Multiple Imputation for Multivariate Missing-Data Problems: A Data Analyst's Perspective. Multivar Behav Res. 1998 Oct 1;33(4):545-71.

36. Lee KJ, Carlin JB. Multiple imputation for missing data: fully conditional specification versus multivariate normal imputation. Am J Epidemiol. 2010 Mar 1;171(5):624-32.

37. OCDE. Health at a Glance 2019: OECD Indicators [Internet]. 2019 [cited $2021 \mathrm{Feb} 12$ ]. (Éditions OCDE). Available from: https://www.oecd-ilibrary.org/social-issues-migrationhealth/health-at-a-glance-2019_4dd50c09-en

38. Eriksson CO, Stoner RC, Eden KB, Newgard CD, Guise J-M. The Association Between Hospital Capacity Strain and Inpatient Outcomes in Highly Developed Countries: A Systematic Review. J Gen Intern Med. 2017 Jun;32(6):686-96.

39. Soremekun OA, Zane RD, Walls A, Allen MB, Seefeld KJ, Pallin DJ. Cancellation of scheduled procedures as a mechanism to generate hospital bed surge capacity-a pilot study. Prehospital Disaster Med. 2011 Jun;26(3):224-9.

40. Boaden R, Proudlove N, Wilson M. An exploratory study of bed management. J Manag Med. 1999 Jan 1;13(4):234-50.

41. Proudlove NC, Gordon K, Boaden R. Can good bed management solve the overcrowding in accident and emergency departments? Emerg Med J. 2003 Mar 1;20(2):149-55.

42. Khanna S, Sier D, Boyle J, Zeitz K. Discharge timeliness and its impact on hospital crowding and emergency department flow performance. Emerg Med Australas EMA. 2016 Apr;28(2):164-70.

43. Champlon S, Cattenoz C, Mordellet B, Roussel-Laudrin S, Jouanny P. Déterminants de la durée de séjour des personnes âgées hospitalisées.

/data/revues/02488663/002900S1/08003007/ [Internet]. 2008 Jun 4 [cited 2019 Jul 27]; Available from: https://www.em-consulte.com/en/article/167730

44. Holstein J, Saint-Jean O, Verny M, Bérigaud S, Bouchon J-P. Facteurs explicatifs du devenir et de la durée de séjour dans une unité de court séjour gériatrique. Sci Soc Santé. 1995;13(4):45-79.

45. Costa AP, Poss JW, Peirce T, Hirdes JP. Acute care inpatients with long-term delayeddischarge: evidence from a Canadian health region. BMC Health Serv Res. 2012 Jun 22;12(1):172.

502 46. Victor CR, Healy J, Thomas A, Seargeant J. Older patients and delayed discharge from 
503 hospital. Health Soc Care Community. 2000;8(6):443-52.

504 47. de Stampa M, Vedel I, Buyck J-F, Lapointe L, Bergman H, Beland F, et al. Impact on

505 hospital admissions of an integrated primary care model for very frail elderly patients. Arch

506 Gerontol Geriatr. 2014 May 1;58(3):350-5.

507 48. Colprim D, Martin R, Parer M, Prieto J, Espinosa L, Inzitari M. Direct Admission to

508 Intermediate Care for Older Adults With Reactivated Chronic Diseases as an Alternative to

509 Conventional Hospitalization. J Am Med Dir Assoc. 2013 Apr 1;14(4):300-2.

510 49. Ingold BB, Yersin B, Wietlisbach V, Burckhardt P, Bumand B, Büla CJ. Characteristics

511 associated with inappropriate hospital use in elderly patients admitted to a general internal

512 medicine service. Aging Milan Italy. 2000 Dec;12(6):430-8.

513 50. Bo M, Fonte G, Pivaro F, Bonetto M, Comi C, Giorgis V, et al. Prevalence of and factors

514 associated with prolonged length of stay in older hospitalized medical patients. Geriatr

515 Gerontol Int. 2016;16(3):314-21.

516 51. Liew D, Liew D, Kennedy MP. Emergency department length of stay independently

517 predicts excess inpatient length of stay. Med J Aust. 2003;179(10):524-6.

518 52. Canac B. Admission directe en court séjour gériatrique: difficultés rencontrées par

519 les médecins généralistes des Alpes-Maritimes. [cited 2021 Mar 3]; Available from:

520 https://core.ac.uk/reader/52775590

521 53. Maréchal F, Kim B-A, Castel-Kremer E, Comte B. Évaluation de la ligne unique et

522 directe d'appel teléphonique en gériatrie (ELUDAT G) : une étude qualitative. NPG Neurol -

523 Psychiatr - Gériatrie. 2015 Dec 1;15(90):316-22.

524 54. Bazin M, Muller M. Le personnel et les difficultés de recrutement dans les Ehpad |

525 Direction de la recherche, des études, de l'évaluation et des statistiques. Etudes Résultats-

526 DREES [Internet]. 2018 Jun [cited 2021 Feb 12]; Available from: https://drees.solidarites-

527 sante.gouv.fr/publications/etudes-et-resultats/le-personnel-et-les-difficultes-de-

528 recrutement-dans-les-ehpad

529 55. Maas ML, Specht JP, Buckwalter KC, Gittler J, Bechen K. Nursing Home Staffing and

530 Training Recommendations for Promoting Older Adults' Quality of Care and Life: Part 1.

531 Deficits in the Quality of Care Due to Understaffing and Undertraining. Res Gerontol Nurs.

5322008 Apr 1;1(2):123-33.

533

534

535

536

537

538

539

540 


\section{DECLARATIONS}

542 Ethics approval and consent to participate. This study was carried out in accordance with

543 relevant guidelines and regulations. It was declared to be of public interest by the National

544 Council for Statistical Information (CNIS) and was integrated into the public statistical program

545 (Visa no. 2013X080SA and publication in the official Journal of French Republic, September 17,

546 2013). It was also approved by the French Data Protection Authority (CNIL) (identification no.

547 1663413). According to French law, written informed consent was not required for this type of 548 study.

550 Consent for publication. According to French law, written informed consent was not required

551 for this type of study. Patients were informed by staff and a short handout and posters were in the 552 waiting area; $0.3 \%$ refused to participate.

553

554 Availability of data and materials. The data that support the findings of this study are available

555 from the French Directorate of Research, Studies, Evaluation and Statistics at the Ministry of 556 Social Affairs and Health (DREES) but restrictions apply to the availability of these data, which

557 were used under license for the current study, and so are not publicly available. Data are however

558 available from the authors upon reasonable request and with permission of the French Directorate

559 of Research, Studies, Evaluation and Statistics at the Ministry of Social Affairs and Health 560 (DREES).

561 Data information and questionnaires are available at the following address

562 http://www.data.drees.sante.gouv.fr/ReportFolders/reportFolders.aspx?IF_ActivePath=P,432,507

$563 \quad 32,507$ 
565 Competing interests. The authors declare no conflicts of interest.

566

567 Funding. This study was funded by the Directorate for Research, Studies, Evaluation and

568 Statistics of the French Health and Social Affairs Ministry (DREES).

569

570 Authors' contributions. DN, YY and NPF were involved in the study data analysis,

571 interpretation of results and drafting of the manuscript. HP was involved in statistical analysis.

572 CEK, PS and JS were involved in study conception. LM was involved in interpretation of the 573 results. All authors critically revised the manuscript.

574

575 Acknowledgment. We thank Dr. Virginie Ringa for her critical review and American Journal

576 Experts (AJE) for English language editing. We also thank all members of the French Society of

577 Emergency Medicine (SFMU) who helped filling the questionnaires on the day of the survey (list 578 available https:/www.sfmu.org/fr/vie-professionnelle/outils-professionnels/referentiels$579 \mathrm{sfmu} / \mathrm{drees} 2013 /)$.

580

581

582

583

584

585

586

587

588 

copayments not covered by public insurance schemes. Below a certain income threshold, individuals can benefit from free supplementary health insurance called Couverture Maladie Universelle Complementary $(C M U-C)$, which can be considered here as a proxy for poor socioeconomic status.

Note: due to multiple imputations, counts have been rounded to the nearest integer

\begin{tabular}{|c|c|c|c|c|c|c|}
\hline & \multicolumn{4}{|c|}{ Hospitalization } & \multirow{2}{*}{\multicolumn{2}{|c|}{ Total }} \\
\hline & \multicolumn{2}{|c|}{$\begin{array}{l}\text { Inter-hospital } \\
\text { transfer }\end{array}$} & \multicolumn{2}{|c|}{$\begin{array}{c}\text { In the same } \\
\text { hospital as the ED }\end{array}$} & & \\
\hline & $\begin{array}{c}N \\
280\end{array}$ & $\%$ col & $\begin{array}{c}N \\
3005\end{array}$ & $\%$ col & $\begin{array}{c}N \\
3285\end{array}$ & $\%$ col \\
\hline \multicolumn{7}{|l|}{ INDIVIDUAL CHARACTERISTICS } \\
\hline \multicolumn{7}{|l|}{ Age } \\
\hline 75-84 years & 143 & 51.1 & 1591 & 52.9 & 1734 & 52.8 \\
\hline More than 85 years or equal & 137 & 48.9 & 1414 & 47.1 & 1551 & 47.2 \\
\hline \multicolumn{7}{|l|}{ Gender } \\
\hline Male & 113 & 40.4 & 1231 & 40.9 & 1344 & 40.9 \\
\hline Female & 167 & 59.6 & 1774 & 59.1 & 1941 & 59.1 \\
\hline \multicolumn{7}{|l|}{ Living conditions } \\
\hline Home & 235 & 83.4 & 2568 & 85.5 & 2803 & 85.3 \\
\hline Institution & 45 & 16.6 & 437 & 14.5 & 482 & 14.7 \\
\hline \multicolumn{7}{|l|}{ Having a GP } \\
\hline No & 3 & 1.5 & 46 & 1.7 & 49 & 1.7 \\
\hline Yes & 277 & 98.5 & 2959 & 98.3 & 3236 & 98.3 \\
\hline \multicolumn{7}{|l|}{ Supplementary health insurance coverage } \\
\hline Private & 243 & 87.0 & 2698 & 89.8 & 2942 & 89.6 \\
\hline Universal complementary health coverage or none & 37 & 13.0 & 307 & 10.2 & 343 & 10.4 \\
\hline \multicolumn{7}{|l|}{ ED VISIT RELATED CHARACTERISTICS } \\
\hline \multicolumn{7}{|l|}{ Presenting complaint } \\
\hline Cardio-pulmonary & 78 & 27.9 & 910 & 30.3 & 988 & 30.1 \\
\hline Neurologic & 28 & 10.0 & 265 & 8.8 & 293 & 8.9 \\
\hline Traumatic injury & 41 & 14.6 & 386 & 12.8 & 427 & 13.0 \\
\hline Other & 133 & 47.5 & 1444 & 48.1 & 1577 & 48.0 \\
\hline \multicolumn{7}{|l|}{ Times of ED arrival } \\
\hline $8 \mathrm{~h}-12 \mathrm{~h}$ & 88 & 31.4 & 789 & 26.3 & 877 & 26.7 \\
\hline $12 \mathrm{~h}-20 \mathrm{~h}$ & 136 & 48.6 & 1609 & 53.5 & 1745 & 53.1 \\
\hline $20 \mathrm{~h}-8 \mathrm{~h}$ & 56 & 20.0 & 607 & 20.2 & 663 & 20.2 \\
\hline How the questionnaire was filled out & & & & & & \\
\hline
\end{tabular}




\begin{tabular}{|c|c|c|c|c|c|c|}
\hline & \multicolumn{4}{|c|}{ Hospitalization } & \multirow{2}{*}{\multicolumn{2}{|c|}{ Total }} \\
\hline & \multicolumn{2}{|c|}{$\begin{array}{l}\text { Inter-hospital } \\
\text { transfer }\end{array}$} & \multicolumn{2}{|c|}{$\begin{array}{c}\text { In the same } \\
\text { hospital as the ED }\end{array}$} & & \\
\hline & $\begin{array}{c}N \\
280\end{array}$ & $\%$ col & $\begin{array}{c}N \\
3005\end{array}$ & $\%$ col & $\begin{array}{c}N \\
3285\end{array}$ & $\%$ col \\
\hline Self reported & 194 & 69.3 & 2243 & 74.6 & 2437 & 74.2 \\
\hline With a proxy & 51 & 18.2 & 462 & 15.4 & 513 & 15.6 \\
\hline No response possible & 35 & 12.5 & 300 & 10.0 & 335 & 10.2 \\
\hline \multicolumn{7}{|l|}{ How the patient reached the ED } \\
\hline By his own means or ambulance & 193 & 69.1 & 2272 & 75.6 & 2466 & 75.0 \\
\hline Firefighters or SAMU & 87 & 30.9 & 733 & 24.4 & 819 & 25.0 \\
\hline \multicolumn{7}{|c|}{ The distance from the patient's home to the ED } \\
\hline Less than $10 \mathrm{~km}$ or equal & 176 & 62.8 & 1657 & 55.0 & 1833 & 55.6 \\
\hline More than $10 \mathrm{~km}$ & 104 & 37.2 & 1348 & 45.0 & 1452 & 44.4 \\
\hline \multicolumn{7}{|c|}{ If the patient was managed in a resuscitation room } \\
\hline No & 217 & 77.4 & 2479 & 82.5 & 2696 & 82.1 \\
\hline Yes & 63 & 22.6 & 526 & 17.5 & 589 & 17.9 \\
\hline \multicolumn{7}{|c|}{ If the ED used was that of the usual place of residence } \\
\hline From the usual living place & 259 & 92.5 & 2812 & 93.9 & 3071 & 93.8 \\
\hline Outside the usual living place & 21 & 7.5 & 193 & 6.1 & 214 & 6.2 \\
\hline \multicolumn{7}{|l|}{ Type of hospitalization ward } \\
\hline Medical ward & 167 & 59.4 & 2069 & 68.8 & 2235 & 68.0 \\
\hline Surgery & 56 & 19.9 & 660 & 22.0 & 716 & 21.8 \\
\hline $\mathrm{ICU}$ & 40 & 14.5 & 241 & 8.0 & 280 & 8.6 \\
\hline Long term care & 11 & 4.0 & 22 & 0.7 & 33 & 1.0 \\
\hline Psychiatry & 6 & 2.2 & 14 & 0.5 & 20 & 0.6 \\
\hline
\end{tabular}




\begin{tabular}{|c|c|c|c|c|}
\hline & \multicolumn{4}{|c|}{ Living conditions } \\
\hline & \multicolumn{2}{|c|}{ Home } & \multicolumn{2}{|c|}{ Institution } \\
\hline & $\mathbf{N}$ & $\%$ col & $\mathbf{N}$ & $\%$ col \\
\hline \multicolumn{5}{|l|}{ INDIVIDUAL CHARACTERISTICS } \\
\hline \multicolumn{5}{|l|}{ Age } \\
\hline $75-84$ years & 1602 & 57.2 & 132 & 27.5 \\
\hline More than 85 years or equal & 1201 & 42.8 & 350 & 72.5 \\
\hline \multicolumn{5}{|l|}{ Gender } \\
\hline Male & 1193 & 42.6 & 151 & 31.0 \\
\hline Female & 1610 & 57.4 & 331 & 69.0 \\
\hline \multicolumn{5}{|l|}{ Having a GP } \\
\hline No & 43 & 1.7 & 6 & 1.7 \\
\hline Yes & 2760 & 98.3 & 476 & 98.3 \\
\hline \multicolumn{5}{|l|}{ Supplementary health insurance coverage } \\
\hline Private & 2508 & 89.5 & 434 & 89.9 \\
\hline Universal complementary health coverage or none & 295 & 10.5 & 49 & 10.1 \\
\hline \multicolumn{5}{|l|}{ ED VISIT RELATED CHARACTERISTICS } \\
\hline \multicolumn{5}{|l|}{ Presenting complaint } \\
\hline Cardio-pulmonary & 848 & 30.2 & 140 & 29.2 \\
\hline Neurologic & 257 & 9.2 & 36 & 7.5 \\
\hline Traumatic injury & 356 & 12.7 & 71 & 14.7 \\
\hline Other & 1342 & 47.9 & 235 & 48.6 \\
\hline \multicolumn{5}{|l|}{ Times of ED arrival } \\
\hline $8 \mathrm{~h}-12 \mathrm{~h}$ & 766 & 27.3 & 111 & 23.2 \\
\hline $12 \mathrm{~h}-20 \mathrm{~h}$ & 1474 & 52.6 & 271 & 55.9 \\
\hline $20 \mathrm{~h}-8 \mathrm{~h}$ & 562 & 20.0 & 101 & 21.0 \\
\hline \multicolumn{5}{|l|}{ How the questionnaire was filled out } \\
\hline Self reported & 2095 & 74.8 & 342 & 70.8 \\
\hline With a proxy & 428 & 15.3 & 85 & 17.7 \\
\hline No response possible & 280 & 10.0 & 55 & 11.5 \\
\hline \multicolumn{5}{|l|}{ How the patient reached the ED } \\
\hline By his own means or ambulance & 2086 & 74.4 & 380 & 78.3 \\
\hline Firefighters or SAMU & 717 & 25.6 & 102 & 21.7 \\
\hline \multicolumn{5}{|l|}{ The distance from the patient's home to the ED } \\
\hline Less than $10 \mathrm{~km}$ or equal & 1570 & 55.9 & 263 & 54.2 \\
\hline More than $10 \mathrm{~km}$ & 1233 & 44.1 & 219 & 45.8 \\
\hline
\end{tabular}




\begin{tabular}{|c|c|c|c|c|}
\hline & \multicolumn{4}{|c|}{ Living conditions } \\
\hline & \multicolumn{2}{|c|}{ Home } & \multicolumn{2}{|c|}{ Institution } \\
\hline & $\mathbf{N}$ & $\%$ col & $\mathbf{N}$ & $\%$ col \\
\hline \multicolumn{5}{|c|}{ If the patient was managed in a resuscitation room } \\
\hline No & 2304 & 82.2 & 392 & 81.1 \\
\hline Yes & 499 & 17.8 & 90 & 18.9 \\
\hline \multicolumn{5}{|c|}{ If the ED used was that of the usual place of residence } \\
\hline From the usual living place & 2615 & 93.7 & 456 & 94.7 \\
\hline Outside the usual living place & 187 & 6.3 & 26 & 5.3 \\
\hline \multicolumn{5}{|l|}{ Type of hospitalization ward } \\
\hline Medical ward & 1909 & 68.1 & 327 & 67.6 \\
\hline Surgery & 603 & 21.5 & 113 & 23.4 \\
\hline ICU & 242 & 8.6 & 38 & 8.2 \\
\hline Long term care & 29 & 1.0 & 4 & 0.7 \\
\hline Psychiatry & 20 & 0.7 & 0 & 0.0 \\
\hline
\end{tabular}

602

603

604

605

606

607

608

609

610

611

612

613

614

615

616

617

618

619

620

621

622

623

624

625

626

627

628

629 
631 Note: County medical density (all specialties combined) was classified into 3 levels according to the 632 National Council of Medical Doctors. In 2013, low, medium, and high levels corresponded to < 302, 302 to 393 and > 393 doctors per 100,000 inhabitants, respectively.

\begin{tabular}{|c|c|c|}
\hline Description of EDs and counties & $\%$ col & $\mathbf{N}$ \\
\hline \multicolumn{3}{|l|}{ CHARACTERISTICS OF HEALTHCARE DEMAND } \\
\hline \multicolumn{3}{|l|}{ ED attendance } \\
\hline Less than 15,000 or equal & 24.1 & 143 \\
\hline $15,001-30,000$ & 42.3 & 251 \\
\hline $30,001-45,000$ & 19.7 & 117 \\
\hline More than 45,001 & 13.8 & 82 \\
\hline \multicolumn{3}{|l|}{ Elderly rate } \\
\hline$<15 \%$ & 54.1 & 321 \\
\hline$\geq 15 \%$ & 45.4 & 269 \\
\hline \multicolumn{3}{|l|}{ County rate of dependent elderly persons } \\
\hline$<20.6 \%$ & 54.5 & 323 \\
\hline$\geq 20.6 \%$ & 45.5 & 270 \\
\hline \multicolumn{3}{|l|}{ Number of access block patients } \\
\hline$<1$ patient/per $100 \mathrm{ED}$ visits & 63.9 & 379 \\
\hline$\geq 1$ patient/per $100 \mathrm{ED}$ visits & 36.1 & 214 \\
\hline \multicolumn{3}{|l|}{ CHARACTERISTICS OF HEALTHCARE SUPPLY } \\
\hline \multicolumn{3}{|l|}{ Type of hospital } \\
\hline Public academic & 9.8 & 58 \\
\hline Public non-academic or Not-for-profit-private hospitals & 71.5 & 424 \\
\hline For-profit private hospitals & 18.7 & 111 \\
\hline \multicolumn{3}{|l|}{ Number of hospitalization beds in acute medical unit in the hospital } \\
\hline$<30$ & 24.6 & 146 \\
\hline $30-49$ & 26.6 & 158 \\
\hline $50-69$ & 21.2 & 126 \\
\hline More than 70 & 22.3 & 132 \\
\hline Missing data & 5.2 & 31 \\
\hline \multicolumn{3}{|l|}{ Rate of geriatric unit beds in the hospital } \\
\hline 0 & 34.1 & 202 \\
\hline $0-10 \%$ & 18.7 & 111 \\
\hline More than $10 \%$ & 30.0 & 178 \\
\hline Missing data & 17.2 & 102 \\
\hline Number of long-term care and nursing home beds per 100,000 & & \\
\hline
\end{tabular}




\begin{tabular}{|c|r|r|}
\hline older than $\mathbf{7 5}$ years in the county & & 275 \\
\hline$<123.4$ & 53.6 & 318 \\
\hline$\geq 123.4$ & & \\
\hline $\begin{array}{c}\text { Proportion of available places in nursing homes for patients older than } \\
\mathbf{7 5} \text { years in the county }\end{array}$ & 63.1 & 374 \\
\hline$<19.6 \%$ & 36.9 & 219 \\
\hline$\geq 19.6 \%$ & & \\
\hline Number of acute care beds per $\mathbf{1 0 0 , 0 0 0}$ inhabitants in the county & 47.6 & 282 \\
\hline$<395$ & 52.4 & 311 \\
\hline$\geq 395$ & & \\
\hline County nurse density for $\mathbf{1 0 0 , 0 0 0}$ persons & 57.7 & 342 \\
\hline$<146$ & 42.3 & 251 \\
\hline$\geq 146$ & & 253 \\
\hline Low & 42.7 & 57.3 \\
\hline County medical density & 340 \\
\hline
\end{tabular}

636

637

638

639

640

641

642

643

644

645

646

647

648

649

650

651

652

653

654

655

656

657

658

659

660

661

662 


\section{Table 5. Multilevel regression model}

664 Note: Adjustment variables (ED level) included in the model were: percentage of elderly, proportion of dependent 665 persons among patients older than 75 years in the county, type of hospital, number of hospitalization beds in the 666 acute medical unit in the hospital, percentage of geriatric unit beds in the hospital, number of long-term care and 667 nursing home beds per 100,000 patients older than 75 years in the county and number of acute care beds per 668100,000 inhabitants in the county

669

670

671

\begin{tabular}{|c|c|c|c|}
\hline Variables & aOR & $95 \% \mathrm{CI}$ & $p$ \\
\hline \multicolumn{4}{|l|}{ Age } \\
\hline $75-84$ years & Ref & . & \\
\hline More than 85 years or equal & 1.17 & $0.93-1.46$ & 0.1740 \\
\hline \multicolumn{4}{|l|}{ Gender } \\
\hline Male & Ref & & \\
\hline Female & 1.00 & $0.80-1.25$ & 0.9959 \\
\hline \multicolumn{4}{|l|}{ Living conditions } \\
\hline Home & Ref & . & \\
\hline Institution & 0.81 & $0.58-1.14$ & 0.2299 \\
\hline \multicolumn{4}{|l|}{ Presenting complaint } \\
\hline Cardio-pulmonary & Ref & . & \\
\hline Neurologic & 1.40 & $0.95-2.08$ & 0.0919 \\
\hline Traumatic injury & 0.77 & $0.52-1.14$ & 0.1962 \\
\hline Other & 1.13 & $0.87-1.47$ & 0.3344 \\
\hline \multicolumn{4}{|l|}{ How the patient reached the ED } \\
\hline By his own means or ambulance & Ref & . & \\
\hline Firefighters or SAMU & 0.65 & $0.47-0.89$ & 0.0094 \\
\hline \multicolumn{4}{|l|}{ Times of ED arrival } \\
\hline $8 \mathrm{~h}-12 \mathrm{~h}$ & Ref & . & \\
\hline $12 \mathrm{~h}-20 \mathrm{~h}$ & 1.80 & $1.36-2.38$ & $<0001$ \\
\hline $20 \mathrm{~h}-8 \mathrm{~h}$ & 1.64 & $1.16-2.31$ & 0.0046 \\
\hline
\end{tabular}





\section{Figures}

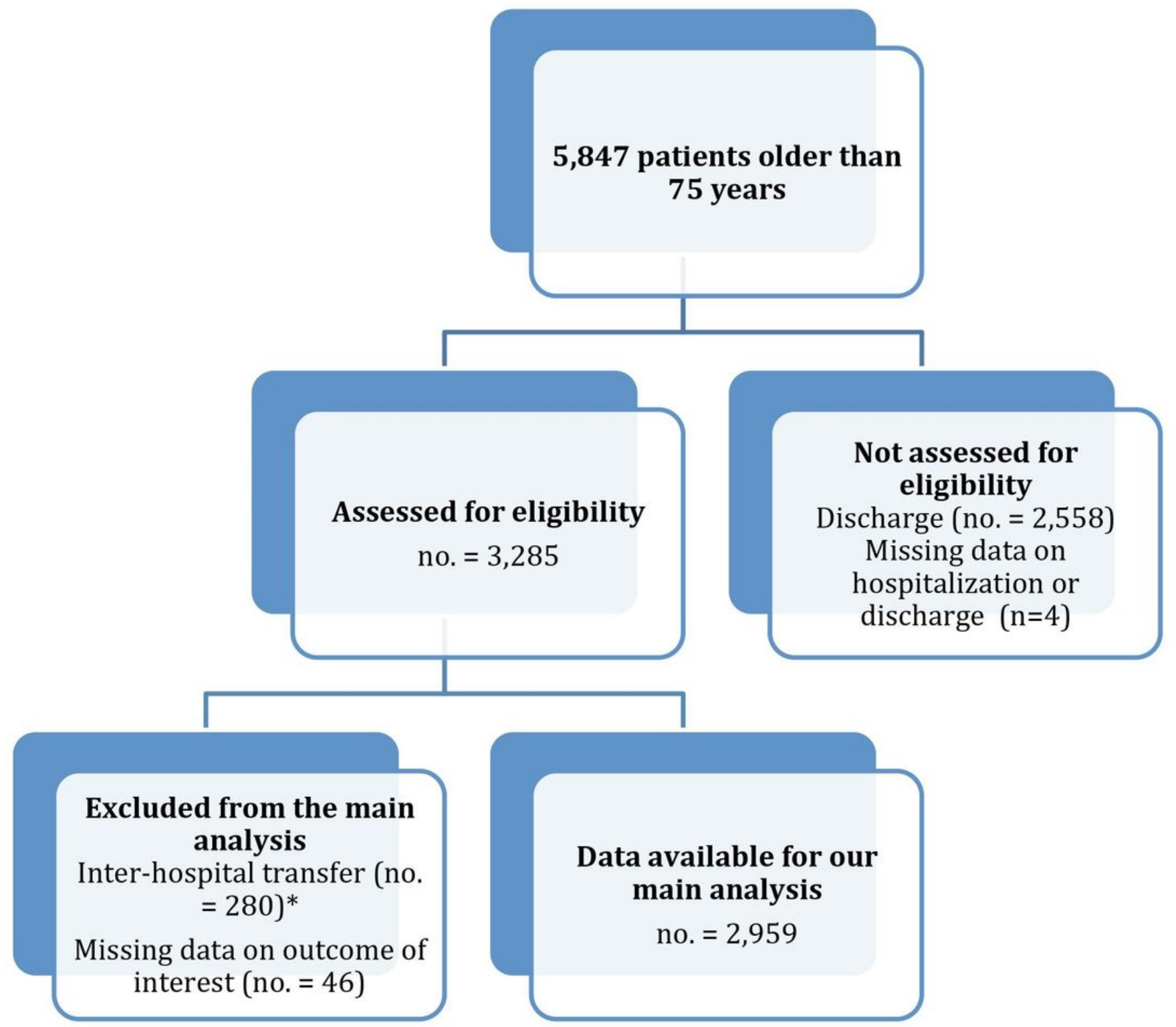

Figure 1

Study flow chart *Interhospital transfers were excluded from the main analysis. However, these patients were included in the sensitivity analysis and were considered admission to an appropriate ward.

\section{Supplementary Files}

This is a list of supplementary files associated with this preprint. Click to download.

- AppendicesFiles.pdf 